\title{
PERBANDINGAN KONDISI PETANI, USAHATANI DAN AKSES PASAR MANGGA DI KECAMATAN GREGED DAN JAPARA
}

\section{COMPARISON OF CONDITIONS OF FARMERS, FARMING AND ACCESS TO MANGO MARKET IN GREGED AND JAPARA DISTRICT}

\author{
Elly Rasmikayati ${ }^{1}$, Ahmad Choibar Tridakusumah ${ }^{1}$, Mochamad Dafa Zikriawan \\ Purnama $^{1}$, Eddy Renaldi ${ }^{1}$, Bobby Rachmat Saefudin ${ }^{2 *}$ \\ ${ }^{1}$ Fakultas Pertanian, Universitas Padjadjaran, Jl. Ry Bandung-Sumedang KM.21 Jatinangor, 45363 \\ ${ }^{2}$ Fakultas Pertanian, Ma'soem University, Jl. Raya Cipacing No. 22 Jatinangor, 45363 \\ *E-mail: bobbyrachmat@masoemunversity.ac.id \\ (Diterima 29-06-2021; Disetujui 22-07-2021)
}

\begin{abstract}
ABSTRAK
Kecamatan Greged, Kabupaten Cirebon dan Kecamatan Japara, Kabupaten Kuningan termasuk ke dalam sentra produksi mangga di Jawa Barat. Kedua daerah tersebut mempunyai potensi dan kelemahannya masing-masing baik dari segi karakteristik petaninya, usahatani dan akses pasar. Tujuan dari penelitian ini adalah untuk mengetahui perbandingan kondisi petani, usahatani dan akses pasar mangga di Kecamatan Greged dan Japara. Metode penelitian menggunakan metode penelitian kuantitatif menggunakan metode survey. Sampel petani ditentukan menggunakan teknik simple random sampling. Dihasilkan 130 sampel petani mangga bagi masing-masing populasi. Alat analisis yang digunakan dalam penelitian ini, yaitu Analisis Deskriptif Distribusi Frekuensi, Uji Two Samples T dan Uji Mann-Whitney U. Hasil penelitian ini menunjukkan bahwa kondisi petani dan usahatani mangga di Kecamatan Greged berbeda secara signifikan dengan Kecamatan Japara pada semua variabel yang dianalisis yaitu jenis kelamin, usia, pekerjaan utama, pendapatan usahatani, jumlah pohon yang dimiliki. Sementara itu untuk akses pasar terdapat 2 variabel yang berbeda secara signifikan, yaitu jarak ke pasar dan waktu tempuh ke pasar.
\end{abstract}

Kata kunci: Karakteristik petani, kondisi usahatani, akses pasar, pemilihan pasar, buah, mangga

\begin{abstract}
Greged District, Cirebon Regency and Japara District, Kuningan Regency are included in the mango production centers in West Java. Both areas have their respective potentials and weaknesses in terms of farmers, farming and market access characteristics. The purpose of this study was to compare the conditions of farmers, farming and market access of mangoes in Greged and Japara Districts. The research method uses quantitative research methods using survey methods. The sample of farmers was determined using simple random sampling technique. There were 130 samples of mango farmers for each population. The analytical tools used in this study are Descriptive Analysis of Frequency Distribution, Two Samples T Test and Mann-Whitney U Test. The results of this study indicate that the condition of farmers and mango farming in Greged District is significantly different from Japara District in all variables analyzed, namely gender, age, main occupation, farm income, number of trees owned. Meanwhile, for market access, there are 2 significantly different variables, namely the distance to the market and the travel time to the market.
\end{abstract}

Keywords: Farmer characteristics, farming conditions, market access, market selection, fruit, mango 


\section{PERBANDINGAN KONDISI PETANI, USAHATANI DAN AKSES PASAR MANGGA \\ DI KECAMATAN GREGED DAN JAPARA}

Elly Rasmikayati, Ahmad Choibar Tridakusumah, Mochamad Dafa Zikriawan Purnama,

Eddy Renaldi,Bobby Rachmat Saefudin

\section{PENDAHULUAN}

Indonesia merupakan produsen mangga terbesar ke-4 di dunia setelah India, China dan Thailand secara rata-rata produksi dari tahun 1994-2018 (Food and Agriculture Organization, 2020). Sentra produksi mangga di Indonesia tersebar ke dalam 10 provinsi berdasarkan luas panen, produksi dan produktivitasnya, yaitu Jawa Timur, Jawa Tengah, Jawa Barat, Nusa Tenggara Barat, Nusa Tenggara Timur, Sulawesi Selatan. Bali, DI Yogyakarta, Aceh dan Banten (Litbang Kementerian Pertanian, 2020). Berdasarkan data Kementerian Pertanian, Provinsi Jawa Barat termasuk ke dalam 10 provinsi tersebut dengan jumlah produksi ke-3 terbanyak setelah Jawa Timur dan Jawa Tengah.

Tabel 1. Luas Panen, Produksi dan Produktivitas Mangga di Provisi Sentral Indonesia Tahun 2019

\begin{tabular}{lccc}
\hline \multicolumn{1}{c}{ Provinsi } & $\begin{array}{c}\text { Luas Panen } \\
\text { (Ha) }\end{array}$ & $\begin{array}{c}\text { Produksi } \\
\text { (Ton) }\end{array}$ & $\begin{array}{c}\text { Produktivitas } \\
\text { (Ton/Ha) }\end{array}$ \\
\hline Jawa Timur & 110165 & 1148121 & 10.42 \\
Jawa Tengah & 53987 & 485041 & 8.98 \\
Jawa Barat & 37539 & 418522 & 11.15 \\
NTB & 12931 & 141794 & 10.97 \\
NTT & 7261 & 51845 & 7.14 \\
Sulawesi Selatan & 14632 & 129432 & 8.85 \\
Bali & 8908 & 65693 & 7.37 \\
DI Yogyakarta & 8244 & 58130 & 7.05 \\
Aceh & 1900 & 21533 & 11.33 \\
Banten & 4558 & 38130 & 8.46 \\
\hline
\end{tabular}

Sumber: Litbang Kementrian Pertanian, 2020

Sentra produksi mangga di Provinsi

Jawa Barat diantaranya adalah Kabupaten

Cirebon, Indramayu, Kuningan,
Majalengka dan Sumedang (BPS Provinsi Jawa Barat, 2016). Jawa Barat menempati urutan ke-3 dari sisi produksi dan menempati urutan ke-2 secara produktivitas. Kemudian pada penelitian Anugrah (2009) disebutkan bahwa jenis mangga utama yang dibudidayakan di sentra produksi mangga Jawa Barat adalah mangga Harumanis, Gedong, Dermayu dan Golek.

Kecamatan Greged merupakan satu sentra produksi mangga di Kabupaten Cirebon, sedangkan Kecamatan Japara adalah sentra produksi mangga di Kabupaten Kuningan. Secara khusus Kecamatan Greged memiliki potensi dari segi pemasarannya dimana petani sudah mudah mendapatkan akses informasi pasar, sistem pembayaran secara tunai, mudahnya syarat akses pasar dan tersedianya sarana transportasi; sedangkan untuk Kecamatan Japara memiliki potensi dari segi usahataninya.

Keberhasilan usahatani mangga ditentukan oleh karakteristik dari petani sebagai pelaku dalam kegiatan usahatani sekaligas pengambil keputusan dalam kegiatan bertani. Karakteristik individu merupakan bagian dari invdividu dan merupakan hal yang melekat pada individu tersebut. Karakteristik juga menjadi dasar seseorang dalam 
bertingkah laku dalam berbagai situasi. (Rogers dan Shoemaker, 1971). Pada penelitian Rasmikayati (2020) mengenai karakteristik individu dan usahatani petani mangga menggunakan tingkat pendidikan, usia, jenis kelamin, pendapatan, pekerjaan, pengalaman usahatani dan sumber modal sebagai variabel yang digunakan dalam penelitiannya. Kemudian pada penelitian yang lain, Rasmikayati (2017) menggunakan variabel usia, tingkat pendidikan dan pengalaman usaha sebagai karakteristik yang memiliki pengaruh terhadap kegiatan agribisnis. Petani dengan usia muda umumnya berpendidikan lebih tinggi, memiliki pengalaman di luar bidang pertanian dan sudah melaksanakan kegiatan agribisnis yang lebih modern.

Usahatani adalah kegiatan bercocok tanam atau berternak yang dilakukan oleh petani, keluarga tani atau dalam bentuk badan usaha lain. Usahatani juga merupakan perusahaan karena memiliki tujuan ekonomi dalam kegiatan produksinya baik dijual maupun dikonsumsi (Mosher, 1983). Pada penelitian Rasmikayati (2020) mengenai karakteristik individu dan usahatani mangga menggunakan variabel tingkat produktivitas, luas lahan yang dikuasai, status penggunaan lahan, dan jumlah pohon mangga untuk mendeskripsikan karakteristik usahatani pada penelitannya. Petani mangga yang memiliki jumlah pohon terbatas kurang berani mengambil risiko produksi tetapi lebih berani mengambil risiko pemasaran sehingga penerimaan pendapatan per pohonnya cenderung rendah (Rasmikayati, 2017).

Kondisi pemasaran mangga di Kabupaten Cirebon dapat diperlihatkan melalui posisi penentuan harga jual yang lemah sehingga harga ditentukan secara searah hal ini dikarenakan jumlah serta mutu produk yang dihasilkan petani tidak selalu sesuai permintaan pasar. Selain itu, petani yang lemah dalam hal permodalan menggunakan pinjaman uang. Hal ini diperburuk dengan adanya pungutan liar dalam pengiriman mangga dari pedagang besar ke agen di pasar-pasar induk yang menambahkan beban biaya (Supriatna, 2010). Pemasaran di Kabupaten Cirebon tepatnya Kecamatan Greged memiliki potensi dengan mudahnya akses mendapatkan informasi, sistem pembayaran sudah dilakukan secara tunai, petani yang memiliki pengetahuan mengenai informasi harga jual, memiliki kendali atas penentuan harga, mudahnya syarat akses pasar dan tersedianya sarana transportasi. Namun, di sisi lain juga 
memiliki kendala dalam cara penjualan mangga yang masih dilakukan melalu pedagang pengumpul atau bandar (Rasmikayati, 2019). Kemudian pada penelitian Rasmikayati et al (2018) menunjukan bahwa petani di Kecamatan Greged Kabupaten Cirebon hanya mampu mengakses pasar tradisional karena kualitas dan kuantitas mangga yang dihasilkan rendah dengan kemampuan produksi mangga grade A/B hanya sebanyak 41-60\% dengan produktivitas tertinggi 151-300 $\mathrm{Kg} /$ pohon. Sehingga pertanian di Cirebon berada pada level transisi dari pertanian subsisten ke pertanian komersil.

Berdasarkan latar belakang tersebut, menarik untuk membuat analisis perbandingan mengenai bagaimana kondisi petani, usahatani dan akses pasar mangga pada petani di Kecamatan Greged, Kabupaten Cirebon dan Kecamatan Japara, Kabupaten Indramayu. Harapannya adalah dapat diketahui kekurangan dan kelebihan dari masing-masing petani di 2 sentra produksi mangga tersebut untuk menciptakan kemampuan untuk mengakses pasar yang lebih baik.

\section{METODE PENELITIAN}

Objek penelitian ini adalah perbandingan kondisi petani, usahatani dan akses pasar mangga di Kecamatan Greged, Kabupaten Cirebon dan Kecamatan Japara, Kabupaten Indramayu yang dipilih sebagai lokasi penelitian secara purposive berdasarkan pertimbangan bahwa Kecamatan Greged dan Japara merupakan bagian dari sentra produksi mangga di Provinsi Jawa Barat.

Desain yang digunakan pada penelitian ini adalah penelitian kuantitatif. Metode penelitian yang digunakan adalah metode survey dan studi literatur.

Variabel yang digunakan dalam penelitian ini meliputi:

1. Karakteristkik Petani

1) Kondisi Petani

a. Jenis Kelamin: Jenis kelamin adalah identitas seksual yang melekat pada diri seseorang, hal ini merupakan bawaan sejak lahir yang mengacu pada kondisi fisik dan biologis pada diri seseorang. Jenis kelamin digolongkan menjadi dua, yaitu laki-laki dan perempuan.

b. Usia adalah satuan waktu yang menjadi tolok ukur dalam mengukur waktu keberadaan suatu benda atau makhluk, baik yang 
hidup maupun yang mati. Umur pun dapat dijadikan tolok ukur dalam melihat aktivitas seseorang dalam bekerja yang mana akan berkaitan erat dengan kondisi fisik seseorang. Umumnya usia terbagi dalam usia produktif dan usia tidak produktif.

c. Pekerjaan utama atau profesi adalah jenis pekerjaan yang menjadi sumber mata pencaharian utama seseorang untuk memperoleh pendapatan guna memenuhi kebutuhan hidupnya. Pekerjaan utama dapat juga diartikan sebagai sebuah pekerjaan yang hanya satusatunya dikerjakan oleh orang tersebut, tetapi jika memiliki pekerjaan lebih dari satu maka pekerjaan utama adalah pekerjaan yang dilakukan dengan memakan waktu terbanyak.

2) Kondisi Usahatani

a. Pendapatan usahatani merupakan selisih dari penerimaan dari hasil penjualan panen mangga dengan sejumlah biaya yang dikeluarkan.

b. Jumlah pohon merupakan banyaknya pohon yang dimiliki petani pada areal kebun yang dikelolanya.
2. Akses Pasar

a. Jarak antar tempat merupakan panjang lintasan yang digunakan untuk mencapai suatu tempat atau tujuan.

b. Waktu tempuh merupakan waktu yang digunakan untuk mencapai suatu tujuan atau tempat.

c. Syarat kualitas produk merupakan ketentuan kualitas yang harus dipenuhi.

d. Syarat kuantitas produk merupakan ketentuan banyaknya pasokan yang harus dipenuhi.

e. Syarat kontinuitas pengiriman merupakan kententuan intensitas pasokan yang harus dipenuhi.

Populasi pada penelitian ini adalah petani mangga di Kecamatan Greged dan Japara dengan jumlah pada masing masing kecamatan sebanyak 230 orang dan 919 orang. Teknik sampling yang digunakan pada penelitian ini adalah simple probability sampling. Dengan tingkat presisi $0,06 \%$ untuk Kecamatan Greged dan 0,085\% untuk Kabupaten Japara, dengan menggunakan rumus slovin didapatkan hasil perhitungan sampel berukuran 126 responden secara proporsional untuk kedua kecamatan, kemudian dibulatkan menjadi masingmasing sebanyak 130 responden. 
Dalam penelitian ini digunakan analisis statistik deskriptif berupa Tabel Distribusi Frekuensi untuk mengidentifikasi deskripsi karakteristik petani, usahatani dan akses pasar mangga. Kemudian untuk melakukan perbandingan antara kedua Kecamatan dilakukan Uji Two Samples T untuk data kuantitatif/metrik dan Uji Mann-Whitney $U$ untuk data kualitatif/non-metrik.

\section{HASIL DAN PEMBAHASAN}

\section{Deskripsi dan Perbandingan Karakteristik Petani Mangga di Kecamatan Greged dan Japara}

Karakteristik petani (kondisi petani dan usahatani mangga) Kecamatan Greged dan Japara pada Tabel 2 menunjukkan bahwa jenis kelamin petani mangga di Kecamatan Greged dan Japara secara mayoritas merupakan laki-laki, hal ini dapat terjadi karena pekerjaan menjadi petani mangga membutuhkan fisik yang kuat untuk melakukan kegiatan budidaya manga. Selain itu, kepala keluarga juga dianggap memiliki tanggung jawab untuk mencari nafkah. Hal ini sejalan dengan yang dikatakan oleh Priyadi (2005) dalam Rahma dkk. (2015) bahwa kegiatan budidaya tanaman lebih banyak dilakukan oleh laki-laki karena tenaga kerja laki-laki lebih kuat, sehingga tepat untuk keperluan budidaya seperti mencangkul, mengoperasikan alat pertanian, dan sebagainya.

Hasil penelitian menunjukkan bahwa terdapat perbedaan signifikan pada jenis kelamin petani antara Kecamatan Greged dan Japara dimana di Kecamatan Japara petani yang berjenis kelamin perempuan lebih banyak dibandingkan petani perempuan di Kecamatan Greged. Kehadiran perempuan didalam usahatani dapat memberikan dampak positif karena perempuan dianggap memiliki kreatifitas lebih dalam kegiatan pemasaran. Seperti yang diungkapkan Elizabeth (2008) dalam (Rahma dkk, 2015) bahwa peran ganda wanita petani sangat strategis dalam peningkatan pendapatan keluarga dan ketahanan pangan. Kemudian Fitmawati (2009) juga menyebutkan bahwa petani perempuan juga lebih mudah dalam mendapatkan kepercayaan peminjaman modal karena dianggap kebih kreatif dalam kegiatan usahataninya. Selain itu, petani perempuan justru lebih suka menjual secara langsung ke pasar dibandingkan dengan melalui perantara. Perempuan lebih terlibat dalam kegiatan pemasaran mangga, terlebih dalam hal distribusi dan menjual mangga dalam kuantitas kecil ke pasar terdekat (Muthini, 2015). 
Usia petani mangga di Kecamatan Greged rata-rata berusia 52 tahun dan Kecamatan Japara berusia 57 tahun. Sesuai dengan yang disebutkan oleh Departemen Kesehatan (2009) bahwa usia 46 hingga 65 tahun termasuk ke dalam usia lansia sehingga usia petani mangga pada kedua kecamatan tersebut tergolong dalam usia lansia. Hasil penelitian menunjukkan bahwa terdapat perbedaan signifikan antara usia petani di Kecamatan Greged dan Japara dimana Kecamatan Japara memiliki proporsi petani berumur lebih dari 66 tahun lebih banyak dibandingkan Kecamatan Greged. Fenomena penuaan petani ini merupakan salah satu permasalahan pembangunan pertanian di Indonesia karena semakin menurunnya minat orang untuk bekerja sebagai petani yang identik dengan pekerjaan kotor dan berpendapatan rendah. Hal ini juga diungkapkan dalam penelitian Rasmikayati dkk. (2017) bahwa berbagai faktor menurunnya minat tenaga kerja petani muda di Indonesia karena citra pertanian yang kurang bergengsi dan berisiko tinggi. Kemudian Rasmikayati (2019) juga menjelaskan anak muda tidak banyak yang memiliki keinginan untuk menjadi petani terlebih sebagai petani mangga.
Terdapat perbedaan pekerjaan sebagai petani mangga antara Kecamatan Greged dan Japara. Bertani mangga pada Kecamatan Greged merupakan pekerjaan utama, sedangkan pada Kecamatan Japara bertani mangga merupakan pekerjaan sampingan. Peralihan profesi dari petani mangga sebagai pekerjaan utama menjadi pekerjaan sampingan dapat terjadi karena adanya tekanan dari pendapatan pertanian yang menurun serta kesenjangan yang semakin melebar antara pendapatan dari bertani dan pekerjaan lain akan meningkatkan tekanan petani untuk mencari pekerjaan lain. Namun, di sisi lain pertanian sebagai pekerjaan sampingan juga memiliki pengaruh untuk mencegah hilangnya petani-petani kecil secara lebih cepat (Gasson, 1986).

$$
\text { Penelitian Rasmikayati }
$$
mengenai pendapatan usahatani mangga mengategorikan tingkat pendapatan petani mangga. Petani yang memiliki pendapatan kurang dari Rp11 juta per musim dikategorikan sebagai petani dengan pendapatan rendah, sedangkan petani dengan pendapatan antara Rp11 juta hingga Rp32 Juta per musim dikategorikan sebagai petani dengan pendapatan sedang dan untuk petani dengan pendapatan lebih dari Rp32 juta 


\section{PERBANDINGAN KONDISI PETANI, USAHATANI DAN AKSES PASAR MANGGA \\ DI KECAMATAN GREGED DAN JAPARA}

Elly Rasmikayati, Ahmad Choibar Tridakusumah, Mochamad Dafa Zikriawan Purnama,

Eddy Renaldi,Bobby Rachmat Saefudin

per musim termasuk ke dalam kategori petani dengan pendapatan tinggi.

Pendapatan usahatani mangga Kecamatan Greged mayoritas termasuk kategori pendapatan sedang, sedangkan untuk Kecamatan Japara mayoritas termasuk kategori pendapatan rendah. Disamping itu pendapatan selain dari usahatani di Kecamatan Greged dan Japara mayoritas termasuk ke dalam kategori rendah. Tingkat pendapatan dapat meningkatkan minat petani untuk tetap menjaga keberlangsungan usahatani mangganya, mengingat usahatani mangga membutuhkan biaya yang tinggi. Jumlah pohon mangga yang dimiliki, penguasaan lahan dan jumlah buah mangga pada setiap pohonnya menjadi penentu dalam pendapatan usahatani mangga, pendapatan yang rendah dapat terjadi karena hanya memiliki pohon mangga yang sedikit, luas lahan yang sempit dan hasil produksi setiap pohonnya yang sedikit. Tingkat pendapatan usahatani mangga menjadi alasan petani untuk tetap melanjutkan kegiatan usahatani, tingginya harga yang ditawarkan meningkatkan pendapatan petani (Saefudin dkk., 2019).
Tabel 2. Deskripsi dan Hasil Uji Beda Karakteristik Petani Mangga di Kecamatan Greged dan Japara

\begin{tabular}{|c|c|c|c|c|c|}
\hline \multirow[b]{2}{*}{ No. } & \multirow{2}{*}{$\begin{array}{c}\text { Karakteristik Petani } \\
\text { Mangga }\end{array}$} & \multicolumn{2}{|c|}{ Kec Greged } & \multicolumn{2}{|c|}{ Kec Japara } \\
\hline & & $\begin{array}{l}\text { Freku- } \\
\text { ensi (n) }\end{array}$ & $\begin{array}{c}\text { Persentase } \\
(\%)\end{array}$ & $\begin{array}{l}\text { Frekuensi } \\
\text { (n) }\end{array}$ & $\begin{array}{l}\text { Persen- } \\
\text { tase (\%) }\end{array}$ \\
\hline \multicolumn{6}{|c|}{1 Jenis Kelamin: } \\
\hline & - Laki-laki & 129 & 99,23 & 98 & 75,38 \\
\hline & - Perempuan & 1 & 0,77 & 32 & 24,62 \\
\hline & Total & 130 & 100,00 & 130 & 100,00 \\
\hline & Nilai Siga & \multicolumn{4}{|c|}{$0,000^{* *}$} \\
\hline \multicolumn{6}{|c|}{2 Usia (Tahun): } \\
\hline & $-<=25$ & 0 & 0,00 & 0 & 0,00 \\
\hline & $-26-45$ & 33 & 25,38 & 24 & 18,46 \\
\hline & $-46-65$ & 92 & 70,77 & 69 & 53,08 \\
\hline & $->65$ & 5 & 3,85 & 37 & 28,46 \\
\hline & Total & 130 & 100,00 & 130 & 100,00 \\
\hline & Nilai Sig ${ }^{\mathrm{a}}$ & \multicolumn{4}{|c|}{$0,000^{* *}$} \\
\hline \multicolumn{6}{|c|}{3 Pekerjaan: } \\
\hline & - Tidak bekerja & 0 & 0,00 & 4 & 3,08 \\
\hline & - Petani mangga & 92 & 70,77 & 6 & 4,62 \\
\hline & - Pedagang & 24 & 18,46 & 6 & 4,62 \\
\hline & - PNS & 0 & 0,00 & 1 & 0,77 \\
\hline & - Bandar & 3 & 2,31 & 0 & 0,00 \\
\hline & - Lainnya & 11 & 8,46 & 113 & 86,92 \\
\hline & Total & 130 & 100,00 & 130 & 100,00 \\
\hline & Nilai Sig ${ }^{\mathrm{a}}$ & \multicolumn{4}{|c|}{$0,000^{* *}$} \\
\hline \multicolumn{6}{|c|}{$\begin{array}{l}\text { Pendapatan } \\
\text { Usahatani: }\end{array}$} \\
\hline & $-<$ Rp 11 juta & 17 & 13,08 & 118 & 90,77 \\
\hline & - Rp 11 juta - 32 juta & 66 & 50,77 & 9 & 6,92 \\
\hline & - >Rp 32 juta & 47 & 36,15 & 3 & 2,31 \\
\hline & Total & 130 & 100,00 & 130 & 100,00 \\
\hline & Nilai Sig ${ }^{\mathrm{a}}$ & \multicolumn{4}{|c|}{$0,000^{* *}$} \\
\hline \multicolumn{6}{|c|}{$\begin{array}{l}5 \text { Jumlah pohon } \\
\text { mangga: }\end{array}$} \\
\hline & $-<50$ pohon & 37 & 28,46 & 117 & 90.00 \\
\hline & - 50 - 100 pohon & 45 & 34,62 & 8 & 6.15 \\
\hline & - >100 pohon & 48 & 36,92 & 5 & 3.85 \\
\hline & Total & 130 & 100,00 & 130 & 100,00 \\
\hline & Nilai Sig $^{\mathrm{a}}$ & \multicolumn{4}{|c|}{$0,000^{* *}$} \\
\hline \multicolumn{6}{|c|}{$\begin{array}{l}\text { Ket: }{ }^{\text {a) }} \text { Berdasarkan hasil Mann-Whitney U Test } \\
\text { b) Berdasarkan hasil Two Independent Samples T Test } \\
\text { *) Signfikan pada taraf nyata } 5 \% \\
\text { **) Signfikan pada taraf nyata } 1 \%\end{array}$} \\
\hline
\end{tabular}

Penelitian Kusumo dkk (2018) mengategorikan petani berdasarkan jumlah pohon mangga yang dimiliki. Dalam penelitian ini petani dengan kepemilikan pohon mangga lebih dari 
100 pohon termasuk ke dalam kategori petani mangga skala besar, sedangkan untuk petani yang mempunyai pohon mangga antara 50 hingga 100 pohon termasuk ke dalam kategori petani mangga skala sedang, dan untuk petani mangga dengan pohon mangga kurang dari 50 pohon termasuk ke dalam petani mangga skala kecil. Petani di Kecamatan Greged rata-rata memiliki jumlah pohon sebanyak 164 pohon yang termasuk ke dalam kategori petani mangga skala besar sedangkan di Kecamatan Japara petani rata-rata memiliki jumlah pohon sebanyak 26 pohon sehingga termasuk ke dalam petani mangga skala kecil. Jumlah kepemilikan pohon juga dapat menunjukkan biaya yang dibutuhkan petani lebih tinggi untuk petani yang memiliki jumlah pohon yang banyak, namun di sisi lain banyaknya jumlah pohon yang dimiliki juga dapat menggambarkan jumlah produksi yang akan didapatkan. Penelitian Rasmikayati dkk. (2017) memperlihatkan bahwa petani dengan kepemilikan pohon mangga dalam jumlah banyak mendapatkan harga buah mangga per kilogram lebih tinggi, selain itu juga menjelaskan petani mangga di Provinsi Jawa Barat lebih banyak petani berskala kecil dibandingkan petani skala sedang dan besar.

\section{Deskripsi dan Perbandingan Karakteristik Petani Mangga di Kecamatan Greged dan Japara}

Akses pasar petani mangga di Kecamatan Greged dan Japara dijelaskan dalam Tabel 3. Jarak ke pasar tujuan bagi mayoritas petani di Kecamatan Greged berada pada jarak lebih dari $40 \mathrm{~km}$ sedangkan untuk petani di Kecamatan Japara jarak ke pasar tujuan bagi mayoritas petani berada pada jarak kurang dari $10 \mathrm{~km}$. Hal ini dikarenakan pemilihan pasar bagi mayoritas petani di Kecamatan Greged adalah secara langsung menuju pasar, sedangkan bagi petani di Kecamatan Japara adalah melalui pedagang perantara yang jaraknya dekat dengan tempat produksi atau pedagang yang langsung mengambil ke tempat produksi. Jarak yang jauh ke pasar juga dapat menunjukkan bahwa tempat produsi mangga di Kecamatan Greged berada pada lokasi yang jauh dari pusat pemukiman penduduk.

Waktu tempuh menuju pasar menurut mayoritas petani mangga di Kecamatan Greged membutuhkan waktu lebih dari 4 jam. Sedangkan untuk mayoritas petani mangga di Kecamatan Japara membutuhkan waktu kurang dari 1 
jam. Hasil penelitian juga menunjukkan bahwa terdapat perbedaan signifikan atas waktu tempuh yang dilalui oleh petani antara kecamatan Greged dan Japara. Waktu tempuh yang berbeda dikarenakan pilihan pasar yang dituju oleh masingmasing kecamatan. Pilihan pasar bagi masing-masing kecamatan telah dibahas sebelumnya. Hal ini menunjukkan adanya pengambilan keputusan yang lebih berisiko dilakukan oleh petani di Kecamatan Greged yang memilih pasar jauh dari tempat produksi. Risiko ini diambil demi mendapatkan pasar yang lebih menguntungkan bagi petani. Mosher (1983) menjelaskan biaya transportasi haruslah semurah mungkin karena biaya transportasi akan memengaruhi biaya lain seperti biaya produksi. Semakin lama waktu tempuh yang dibutuhkan menuju pasar akan semakin meningkatkan biaya transportasi yang dibutuhkan. Dalam hal ini Kecamatan Greged secara mayoritas membutuhkan biaya transportasi yang lebih tinggi dibandingkan petani di Kecamatan Japara karena membutuhkan waktu tempuh yang lebih lama dilihat dari jarak tempuh, juga petani di Kecamatan Greged menempuh jarak yang lebih jauh jika dibandingkan dengan Kecamatan Japara. Meskipun secara mayoritas di Kecamatan Greged tetap memilih untuk menjual secara langsung ke pasar. Hal ini dikarenakan petani di Kecamatan Greged memiliki kendaraan untuk menempuh pasar tersebut. Menurut Fischer \& Qaim (2012), petani yang memiliki kendaraan menjadi lebih mudah mengakses pasar utama yang terletak jauh dengan biaya yang lebih rendah dan waktu yang lebih singkat dibandingkan dengan mereka yang tidak memiliki akses transportasi. Hal ini juga dapat disebabkan karena pedagang perantara yang menjadi pilihan petani di Kecamatan Japara berada dekat dengan tempat produksi.

Pedagang perantara merupakan pilihan pasar yang paling mudah dan cepat karena tidak terdapat syarat kualitas, kuantitas dan kontinuitas yang berarti bagi petani. Selain itu, pedagang perantara juga menawarkan kemudahan dalam pemberian modal bagi petani namun dengan syarat seluruh hasil produksinya harus dijual kepada mereka. Penjualan secara langsung ke pasar memberikan keuntungan bagi petani dari segi harga jual, namun di sisi lain petani juga harus mengambil risiko-risiko pemasaran seperti pengeluaran biaya tambahan untuk kegiatan distribusi. Pasar modern dan ekspor sebagai pasar yang 
memberikan keuntungan paling tinggi bagi petani memiliki syarat pasar yang sulit bagi petani, syarat tersebut menjadi risiko bagi petani mangga jika produknya gagal memenuhi syarat tersebut. Pada penelitian ini petani di Kecamatan Greged berani mengambil risiko untuk menjual hasil produksi ke pasar secara langsung dengan dukungan ketersediaan transportasi yang dimiliki sehingga risiko dalam distribusi berani mereka tempuh. Hal ini juga dimotivasi oleh penguasaan lahan dan jumlah pohon yang mereka miliki, menggambarkan tingginya hasil produksi membuat mereka merasa pantas untuk mendapatkan harga yang lebih baik untuk hasil produksi mereka. Kemudian dari segi pendapatan petani di Kecamatan Greged memiliki pendapatan kategori sedang hingga tinggi yang cukup banyak menunjukkan terbebasnya mereka dari tekanan ekonomi untuk menjual hasil produk secara cepat. Namun dari segi syarat pasar menunjukkan pasar langsung juga secara mayoritas masih belum menerapkan syarat kuantitas, kualitas maupun kontinuitas. Hal ini diduga karena kegiatan penyortiran dilakukan oleh pedagang di pasar itu sendiri yang kemudian akan dilakukan penjualan sesuai dengan kualitas masing-masing produk.
Tabel 3. Deskripsi dan Hasil Uji Beda Karakteristik Petani Mangga di Kecamatan Greged dan Japara

\begin{tabular}{|c|c|c|c|c|c|}
\hline \multirow[b]{2}{*}{ No. } & \multirow{2}{*}{$\begin{array}{c}\text { Karakteristik Petani } \\
\text { Mangga }\end{array}$} & \multicolumn{2}{|c|}{ Kec. Greged } & \multicolumn{2}{|c|}{ Kec. Japara } \\
\hline & & $\begin{array}{l}\text { Freku- I } \\
\text { ensi (n) }\end{array}$ & $\begin{array}{l}\text { Persentase } \\
(\%)\end{array}$ & $\begin{array}{l}\text { Frekuensi } \\
(\mathrm{n})\end{array}$ & $\begin{array}{l}\text { Persen- } \\
\text { tase (\%) }\end{array}$ \\
\hline \multicolumn{6}{|c|}{1 Jarak Ke Pasar Akhir: } \\
\hline & $-<10 \mathrm{Km}$ & 85 & 65,38 & 13 & 10,00 \\
\hline & $-10-20 \mathrm{Km}$ & 0 & 0,00 & 1 & 0,77 \\
\hline & $-20-30 \mathrm{Km}$ & 3 & 2,31 & 8 & 6,15 \\
\hline & $-30-40 \mathrm{Km}$ & 27 & 20,77 & 15 & 11,54 \\
\hline & - $>40 \mathrm{Km}$ & 15 & 11,54 & 93 & 71,54 \\
\hline & Total & 130 & 100,00 & 130 & 100,00 \\
\hline & Nilai Sig ${ }^{a}$ & \multicolumn{4}{|c|}{$0,000^{* * *}$} \\
\hline \multicolumn{6}{|c|}{2 Waktu Tempuh: } \\
\hline & $-<1 \mathrm{Jam}$ & 13 & 10,00 & 100 & 76,92 \\
\hline & - 1-2 Jam & 29 & 22,31 & 12 & 9,23 \\
\hline & - 2-3 Jam & 0 & 0,00 & 6 & 4,62 \\
\hline & - 3-4 Jam & 3 & 2,31 & 2 & 1,54 \\
\hline & - >4 Jam & 85 & 65,38 & 10 & 7,69 \\
\hline & Total & 130 & 100,00 & 130 & $\overline{100,00}$ \\
\hline & Nilai Sig & \multicolumn{4}{|c|}{$0,000^{* *}$} \\
\hline \multicolumn{6}{|c|}{$\begin{array}{l}3 \text { Syarat Kualitas } \\
\text { Produk: }\end{array}$} \\
\hline & - Ada & 39 & 30,00 & 29 & 22,31 \\
\hline & - Tidak & 91 & 70,00 & 101 & 77,69 \\
\hline & Total & 130 & 100,00 & 130 & $\overline{100,00}$ \\
\hline & Nilai Siga & \multicolumn{4}{|c|}{0,159} \\
\hline \multicolumn{6}{|c|}{4 Syarat Kuantitas : } \\
\hline & - Ada & 1 & 0,77 & 0 & 0,00 \\
\hline & - Tidak & 129 & 99,23 & 130 & 100,00 \\
\hline & Total & 130 & 100,00 & 130 & $\overline{100,00}$ \\
\hline & Nilai Sig ${ }^{a}$ & \multicolumn{4}{|c|}{0,317} \\
\hline \multicolumn{6}{|c|}{5 Syarat Kontinuitas: } \\
\hline & - Ada & 4 & 3,08 & 1 & 0,77 \\
\hline & - Tidak & 126 & 96,92 & 129 & 99,23 \\
\hline & Total & 130 & 100,00 & 130 & $\overline{100,00}$ \\
\hline & Nilai Sig ${ }^{\mathrm{a}}$ & \multicolumn{4}{|c|}{0,176} \\
\hline \multicolumn{6}{|c|}{$\begin{array}{l}\text { Ket: }{ }^{\text {a) }} \text { Berdasarkan hasil Mann-Whitney U Test } \\
\text { b) Berdasarkan hasil Two Independent Samples T Test } \\
\text { *) Signfikan pada taraf nyata } 5 \% \\
\text { **) Signfikan pada taraf nyata } 1 \%\end{array}$} \\
\hline
\end{tabular}

Bagi petani di Kecamatan Japara kegiatan usahatani mangga tidak menjadi prioritas mereka mengingat bekerja sebagai petani mangga hanyalah pekerjaan sampingan bagi mereka. Hal ini pula dapat menjadi faktor pendorong bagi mereka untuk menjual hasil 
usahataninya melalui pedagang perantara yang mudah dan cepat mengingat kegiatan usahatani mangga bukan prioritas mereka. Selain itu, hambatan dalam ketersediaan transportasi juga menjadi bagian yang menyebabkan petani mangga di Japara memilih menjual melalui pedagang perantara. Kemudian juga tekanan secara ekonomi untuk mendapatkan uang dari hasil usahatani secara cepat dapat membuat petani harus menjual hasil panennya secara cepat.

Perbedaan karakteristik petani dan perbedaan akses pasar yang dimiliki petani antara Kecamatan Greged dan Japara mampu membedakan hasil akhir dari pasar yang dituju oleh petani. Kemudahan akses menjadi motivasi petani untuk lebih berani mengambil risiko pemasaran. Dalam hal akses pasar pula dapat terlihat bahwa pedagang memiliki kendali lebih atas pemasaran yang dilakukan petani mangga dimana pedagang berpartisipasi pada kegiatan produksi juga pemasarannya. Hal ini juga yang menjadi alasan mengapa pedagang memiliki akses informasi yang lebih baik dibandingkan petani.

\section{KESIMPULAN}

Perbandingan kondisi petani dan usahatani mangga di Kecamatan Greged dan Japara yaitu petani dengan jenis kelamin perempuan di Kecamatan Japara lebih banyak dibandingkan Kecamatan Greged. Petani di Kecamatan Greged lebih banyak yang berusia produktif sedangkan di Kabupaten Japara lebih banyak yang sudah sepuh. Di Kecamatan Greged pekerjaan utama merupakan sebagai petani mangga sedangkan di Kecamatan Japara petani mangga merupakan pekerjaan sampingan, petani di Kecamatan Greged memiliki pendapatan yang lebih tinggi baik dari usahatani maupun selain usahatani, dan jumlah pohon yang dimiliki petani di Kecamatan Greged lebih banyak. Semua variabel kondisi petani dan usahatani mangga di Kecamatan Greged sangat berbeda secara signifikan dibandingkan Japara.

Akses pasar mangga di Kecamatan Greged dan Japara yang berbeda signifikan adalah jarak ke pasar akhir dan waktu tempuh. Sedangkan untuk syarat kualitas, kuantitas dan kontinuitas produk perbedaannya tidak signifikan. Bagi petani di Kecamatan Greged, jarak ke pasar akhir ditempuh lebih jauh dan waktu tempuh ke pasar ditempuh lebih lama. Hampir semua petani di kedua Kecamatan menyatakan bahwa tidak ada persyaratan dari pasar terkait syarat 
kualitas, kuantitas dan kontinuitas produk mangga yang mereka jual.

\section{DAFTAR PUSTAKA}

Anugrah, I. S. (2009). Mendudukkan Komoditas Mangga Sebagai Unggulan Daerah Dalam Suatu Kebijakan Sistem Agribisnis : Upaya Menyatukan Dukungan Kelembagaan Bagi Eksistensi Petani. Analisis Kebijakan Pertanian, 189-211.

Fischer, E., \& Qaim, M. (2012). Linking Smallholders to Market: Determinants and Impacts of Farmer Collective Action in Kenya. World Development, 1255-1268.

Food and Agriculture Organization. (2020, Oktober 10). Diambil kembali dari Food and Agriculture Organization website: http://www.fao.org/faostat/en/\%22 $\% 20 \% 5 \mathrm{Cl} \% 20 \% 22$ data/QC/visuali ze

Gasson, R. (1986). Part Time Farming Strategy For Survival. Journal of the European Society for Rural Sociology, 364-376.

Kusumo, R. A. B., Rasmikayati, E., Karyani, T., \& Mukti, G. W. (2019). PERBANDINGAN PERILAKU USAHATANI PADA DUA SENTRA PRODUKSI MANGGA DI PROVINSI JAWA BARAT (Kasus di Kabupaten Indramayu dan Kuningan). Mimbar Agribisnis: Jurnal Pemikiran Masyarakat Ilmiah Berwawasan Agribisnis, 5(2), 134-144.

Litbang Kementrian Pertanian. (2020, September 18). Diambil kembali dari Inagrimap webstie: http://inaagrimap.litbang.pertanian. go.id/index.php/sentraproduksi/tanaman-buahbuahan/mangga
Mosher, A. (1983). Menggerakkan dan Membangun Pertanian. New York: C.V. Yasaguna.

Muthini, D. N. (2015). An Assessment of Mango Farmers Choice of Marketing Channels. Thesis.

Rahma, A., Puspitawati, H., \& Herawati, T. (2015). Pengaruh peran gender dan pemeliharaan lingkungan mikro terhadap kesejahteraan subjektif keluarga petani dataran tinggi. Jurnal Ilmu Keluarga \& Konsumen, 8(2), 69-79.

Rasmikayati, E., Azizah, M. N., \& Saefudin, B. R. (2019). Potensi dan Kendala yang Dihadapi Petani Mangga dalam Mengakses Lembaga Pemasaran (Studi Kasus Di Kecamatan Greged Kabupaten Cirebon). Paradigma Agribisnis, 2(1), 22-30.

Rasmikayati, E., Kusumo, R. A. B., Sukayat, Y., Arisyi, Y. H., \& Saefudin, B. R. (2020). Karakteristik Individu Dan Usahatani Petani Mangga Yang Melakukan Kemitraan Pemasaran Di Kecamatan Sindangkasih Kabupaten Majalengka. Paradigma Agribisnis, 3(1), 12-23.

Rasmikayati, E., Setiawan, I., \& Saefudin, B. R. (2017). Kajian Karakteristik, Perilaku dan Faktor Pendorong Petani Muda Terlibat dalam Agribisnis pada Era Pasar Global. Mimbar Agribisnis: Jurnal Pemikiran Masyarakat Ilmiah Berwawasan Agribisnis, 3(2), 134149.

Rasmikayati, E., Sulistyowati, L., \& Saefudin, B. R. (2017). Risiko Produksi dan Pemasaran Terhadap Pendapatan Petani Mangga: Kelompok Mana yang Paling Berisiko. Mimbar Agribisnis: Jurnal Pemikiran Masyarakat Ilmiah Berwawasan Agribisnis, 3(2), 105-116. 


\section{PERBANDINGAN KONDISI PETANI, USAHATANI DAN AKSES PASAR MANGGA \\ DI KECAMATAN GREGED DAN JAPARA}

Elly Rasmikayati, Ahmad Choibar Tridakusumah, Mochamad Dafa Zikriawan Purnama,

Eddy Renaldi,Bobby Rachmat Saefudin

Rasmikayati, E., Sulistyowati, L., Karyani, T., \& Saefudin, B. R. (2018). Dinamika Perilaku Agribisnis Petani Mangga Di Kecamatan Greged Kabupaten Cirebon. Paradigma Agribisnis, $1(1), 14-26$.

Saefudin, B. R., Rasmikayati, E., Dwirayani, D., Awaliyah, F., \& Rachmah, A. R. A. (2020). Fenomena Peralihan Usahatani
Mangga Ke Padi Di Kecamatan Sedong, Kabupaten Cirebon, Jawa Barat. Paradigma Agribisnis, 2(2), 21-33.

Supriatna, A. (2010). Analisis Pemasaran Mangga "Gedong Gincu" (Studi Kasus di Kabupaten Cirebon, Jawa Barat). Agrin, 97-113. 